\title{
Cottage Industry, Migration and Marriage in Nineteenth-Century England
}

Since the 1970s proponents of the theory of 'proto-industrialization' have argued that in areas of rural industry marriages tended to take place earlier, and in consequence levels of overall fertility tended to be higher than in other rural—but more strictly agricultural - areas. Marriage could take place more freely where the bargain between land and dowry had no relevance, and was facilitated by greater access to both independent earnings and wage incomes. Simultaneously, demand for labour rendered children an economic asset, and hence encouraged higher levels of marital fertility and put a premium upon the retention of older children at home, producing larger, more complex families and more rapid rates of population growth. ${ }^{1}$

In the classic formulation 'proto-industry' was cottage based, with the household as the essential unit of production, involved the production of goods for export and not merely local markets, and created interdependent zones of rural industry and commercial farming. It tended to take hold in pastoral areas where agricultural labour suffered from under-employment and hence the opportunity cost of that labour was low, although there are examples of its development in areas of arable cultivation too. As the definition of the prefix 'proto' would suggest - 'first in time, earliest, original, primitive' - it tends to presume subsequent industrialization proper in the form of modern factory-based industry, although to avoid the consequence of a teleological 
paradox the possibility of subsequent de-industrialization has been built into the model too. This is, of course, one particularly problematic feature of the thesis, for no clear, general explanation has been offered to explain these divergent paths in different regions. Another problem is its limited application, for its exponents concentrate almost solely upon the various textile industries which—while important—formed only part of the multi-faceted process of industrialization. Furthermore, in practice its chronological application is quite limited, the central focus falling upon the late seventeenth and eighteenth centuries, even though peasant production for distant markets was anything but new to these years and family-based, cottage industry persisted in England in many areas far into the nineteenth century. Indeed, it was an essential part of the process of industrialization in that century, and not merely a residual hangover of a mode of production whose time has passed.

To pursue possible links between areas of industrial development and patterns of marriage and fertility does not, however, demand the adoption of a strict and fullblown proto-industrial model, and such connexions had, in fact, been postulated long before the 'demo-economic system of proto-industrialization' was developed by Hans Medick. $^{2}$ In his classic regional study of the Vale of Trent 1670-1800, J.D. Chambers suggested just such a connexion twenty years earlier. ${ }^{3}$ Framework knitting developed rapidly in this region during the late seventeenth and early eighteenth centuries, to be followed by fuller development of the cotton and iron industries in the second half of the century, and the evolution of large-scale, centralized production. ${ }^{4}$ To demonstrate the demographic implications of the first phase of this process of industrialization 
Chambers compared aspects of the demographic experience of 34 agricultural villages and 26 industrial villages in the region in the 1740s, examined ages at marriage by socio-occupational group for the years 1701-53 from extant Nottinghamshire marriage certificates and calculated baptism/marriage ratios across the whole century. ${ }^{5}$ His results indicate an unequivocal relationship between rural industrialization, a lower age at marriage and a higher rate of marital fertility. As the impact of epidemic disease, especially upon children, declined, and with the assistance of immigration, this became 'an effective instrument of population growth for the first time in the history of industrial populations' ${ }^{6}$ The aggregate demographic techniques he used, of course, might be regarded as somewhat crude, and the respective impact of birth, death and migration are admittedly difficult to disentangle. But reconstitution studies provide support, showing that, while age at marriage for women fell between the later seventeenth and early nineteenth centuries in all reconstitutions completed to date, the decline was above the average in industrial villages such as Shepshed in Leicestershire and Gedling in Nottinghamshire. ${ }^{7}$ Unfortunately only three out of 26 reconstitutions currently available relate to industrial villages, and although there was indeed a particularly steep fall in female age at marriage across the eighteenth century in these three, by the early nineteenth century it was still only slightly below that found elsewhere. ${ }^{8}$ Furthermore, a recent study of the two textile townships of Calverley and Sowerby in West Yorkshire casts further doubt upon the inevitability of such as association, for in Calverley female age at marriage remained low and stable across the century, while in Sowerby it fell far less that in Shepshed or Gedling. Calverley, however, witnessed a much greater 
increase in marital fertility, but in both townships there is evidence to suggest that the averages that can be calculated were disproportionately influenced by the extreme behaviour of particular sub-groups within their populations, rather than reflecting the general of experience of the majority. ${ }^{9}$

Turning to the nineteenth century, it was suggested by Ogle as long ago as 1890, on the basis of an analysis of the 1881 census and marriage registration data, that female employment opportunities encouraged early marriage, for 'men might not unnaturally be more ready to marry girls or young women who were themselves earning money'. ${ }^{10}$ Contemporary opinion provides some support, suggesting that the accumulation of a modicum of savings, by both sexes, was a common prerequisite to marriage: the Rev. J. Howlett wrote in 1795 that among farm servants 'the young man [who] can scrape up $£ 20$ or $£ 30$ and finds a young woman possessed with nearly an equal sum' could then embark on marriage, while another source from Hertfordshire in 1817 suggested that a normal precondition would be the accumulation of a combined sum of $£ 40 .{ }^{11}$ Contrary to Ogle, however, Snell and others have suggested that in rural areas farm service pulled in the opposite direction, restricting the opportunity to marry while at the same time allowing the accumulation of those savings that would eventually smooth its path. ${ }^{12}$

In 1976 Anderson published an important article that examined variations in nuptiality by registration district across the whole of England and Wales in $1861 .^{13}$ Although the proportion of males in industrial occupations tended to raise levels of 
nuptiality, his conclusion was that industrialization per se does not appear to have been closely related to marriage or marital fertility, although female employment outside the home — particularly in domestic service — was important in delaying marriage and reducing the proportions marrying, while a further important influence was changing employment patterns in agriculture as day labourers replaced farm servants. The sex ratio of the population, particularly at extreme values, was a further important factor tending to constrain marriage chances. Further exploration of Victorian marriage patterns by Woods and Hinde, employing registration level census data from 1861 and 1891 alongside more detailed analysis of six case study districts with contrasting employment structures - while suggesting lower levels of variation than Anderson found - reinforced many of his conclusions. ${ }^{14}$ Coalfield communities exhibited high rates of nuptiality, while in towns with large numbers of domestic servants marriage was delayed, as it was in areas where farm service persisted. Marriages were relatively late in textile towns, although as married women sometimes continued to work in textile mills the impact of non-domestic female employment 'is not as easily evaluated [and] need not necessarily have influenced nuptiality': similarly, it is suggested, this issue was left 'in some doubt' by Anderson's analysis, which revealed an inverse relationship, but only a relatively weak one. ${ }^{15}$ The importance of employment as a force conditioning marital behaviour remains 'overwhelming', however, while it is also clear that regional and even local variations in marriage patterns could be a product of different social and demographic environments. $^{16}$ 
Such nuanced and qualified conclusions are not always entirely accurately reflected in the statements found in general textbooks, one baldly stating that between the 1830 s and the 1890 s there were 'considerable differences between the industrial areas (where there were more and earlier marriages) and the rural areas (where marrriage tended to be later)', while 'economic incentives to limiting the number and spacing of births were strong where women were prominent in the workforce'. ${ }^{17}$ This goes well beyond the conclusions of Anderson, or Woods and Hinde, although Woods' most recent statement is firmer, a fuller analysis of the impact of female employment upon nuptiality by registration district for 1861,1891 and 1911 leading him to conclude that

wage labour among women has an adverse effect on nuptiality. It is quite clear why this should be so in the case of domestic servants, but the opportunities for women to find non-domestic employment also served to delay marriage. The most important instance of this phenomenon occurred in the textile districts where mill employment among young women represented a distinct and nearly universal stage in the life cycle. ${ }^{18}$

Women textile workers, rather than non-domestic employees generally, feature in Woods' analysis of marital fertility, and leads to the further conclusion that 'Both nuptiality and marital fertility are likely to be depressed as a result of greater employment opportunities for women and the possibility of remaining at or returning to work when married with young children'. ${ }^{19}$

The results discovered in micro-histories, must, however, give pause for thought, for they reveal aspects of demographic behaviour that fail to conform to simple generalizations or established orthodoxy. In Blean in Kent, for example, the average 
age of those women who married labouring men in the early nineteenth century, just 22 , was remarkably low, and some 50 per cent of labouring brides in the early years of the century were aged 20 or younger. ${ }^{20}$ The study of Calverley and Sowerby, cited above, has also thrown up a range of variant patterns which counsel strongly against over-generalization. Woods too notes that 'Local circumstances were especially important in conditioning and constraining the choice of marriage partners', as studies of Sheffield and Keighley, and a selection of parishes with contrasting economic structures analyzed by Hinde, have shown. ${ }^{21}$ Micro-history, of course, is extremely time-consuming, and hence such work has a high opportunity cost: 'total reconstitution' at the level of the individual parish provides slow, if insightful, progress. Local studies of particular parishes or small groups of parishes using the census enumerators' books as the key source are less prohibitive to the individual researcher, but tend to represent isolated instances of communities identified by broad typologies, and to date have focused largely upon female employment in textiles. Studies based upon national census reports and vital registration data, however, suffer from the very breadth of the canvas, allowing insufficient attention to be paid to local variations in socio-economic conditions, and-particularly in view of the fact that the census report of 1861 only records the occupations of women aged 20 and over-can fail to identify fully the occupational profile of individual districts. This is even true of Woods' analysis, where 614 districts are defined for England and Wales: they cannot completely capture all local employment markets, nor do justice to local variations in many economic and social, or demographic, indicators. The need to rely 
heavily upon the 1861 census for detailed occupational information is another drawback of work conducted at this level.

The approach adopted here represents a bridge between the employment of individual level and national data through a focus upon a single county, the county of Hertfordshire, and combines the registration district and sub-district level data available from the Registrar Generals' reports after 1837 with detailed analysis of the socio-occupational structure of the county established from the census enumerators' books, rather than from the printed reports, allied to demographic analysis from the same source down to the level of the individual parish. It thus offers an analysis of a contiguous geographical area of approximately 400,000 acres with a clearly defined boundary, informed by knowledge of the broad socio-economic characteristics of that area, of variations within it, and of how these changed over time. The focus of the study is the manner in which employment opportunities for women and children in cottage industry, rather than factory employment, impacted upon marriage, a subject not explicitly tackled in recent nineteenth-century research. It is also a subject for which the county of Hertfordshire, where the straw plait and hat trades were thriving during the first three-quarters of the nineteenth century, provides a highly suitable case for treatment.

\section{II}

Despite the peripheral place they usually occupy in general histories of industrialization, the straw plait and hat trades were of vital importance to the 
Table 1. Female straw plait and hat workers in six English counties, and England and Wales, 1841-1901

\begin{tabular}{|l|r|r|r|r|r|r|r|}
\hline & 1841 & 1851 & 1861 & 1871 & 1881 & 1891 & 1901 \\
\hline Bedfordshire & 2,387 & 15,156 & 19,262 & 20,701 & 15,058 & 10,191 & 8,215 \\
\hline Buckinghamshire & 1,276 & 3,180 & 3,364 & 3,412 & 1,654 & 515 & 182 \\
\hline Essex & 605 & 3,440 & 2,647 & 2,839 & 922 & 37 & 7 \\
\hline Hertfordshire & 4,590 & 10,518 & 10,694 & 12,089 & 7,543 & 3,133 & 1,979 \\
\hline Middlesex & 2,242 & 4,454 & 3,567 & 903 & 534 & 363 & 308 \\
\hline Suffolk & 303 & 2,572 & 2,001 & 2,335 & 776 & 38 & 1 \\
\hline & & & & & & & \\
\hline Total & 11,403 & 39,320 & 41,535 & 42,279 & 26,487 & 14,277 & 10,692 \\
\hline & & & & & & & \\
\hline $\begin{array}{l}\text { England \& } \\
\text { Wales }\end{array}$ & 22,202 & 54,212 & 50,103 & 45,270 & 27,983 & 14,959 & 10,874 \\
\hline
\end{tabular}

economies of Hertfordshire, Bedfordshire, Buckinghamshire and Essex in the nineteenth century. Straw plaiting and hatmaking was already in evidence in these counties in the later seventeenth and eighteenth centuries, benefited considerably from the embargo on imported straw during the Napoleonic Wars, and continued to thrive - despite periodic setbacks — through into the third quarter of the nineteenth century. The figures presented in Table 1, for females employed in straw plaiting from 1841 to 1891 , indicate its importance and progress over time. ${ }^{22}$ Far from disappearing towards the mid-nineteenth century as mechanization took hold in many industries and England became the 'workshop of the world', straw plait and hatmaking continued to expand, not reaching its peak until 1871, by which time some other traditional, local handicraft industries_-such a lace-making — had long since been in decline. Straw hatmaking held on better than straw plaiting, for it was the import of cheap straw plait from Japan and China that killed the plaiting trade, not 
mechanization from within, and the impact was dramatic. In Hertfordshire the number of female straw plait and hatmakers almost halved in the 1870s, and halved again in

\section{[ Figure 1 here ]}

the 1880s, although even in 1891 it retained a significant—if rapidly decliningpresence in many Hertfordshire parishes. It was plaiting by children that fell away most dramatically, and hence the rate of decline indicated in Table 1 was lower among adult plaiters. Bonnet sewing may have provided compensation, and the appearance of a new occupational descriptor, 'straw hat machinist', indicates adaptability to new technology. Nevertheless, there can be no doubt that by 1891 the industry was in an advanced state of contraction, and wages fell simultaneously, soon rendering the trade 'starving work' according to the few plaiters remaining around Chelmsford in Essex in 1881. By 1910, Mr Maberly Phillips could write of Hertfordshire in The Connoisseur that 'only a few veterans of the art are left', and by this time the rewards were derisory. ${ }^{23}$

Even less well known is the precise regional location of the industry, which was very heavily concentrated in the west and particularly the south-west of Hertfordshire and had relatively little impact elsewhere, despite the fact that it was also found in parts of Essex to the east. It was in fact only prominent in four of the county's twelve Superintendent Registrar's Districts (SRDs): Berkhamsted, St Albans, Hemel Hempstead and Hitchin (see Figure 1). ${ }^{24}$ This concentration is reflected in the extent 
of both female and child employment across the county, for among adults the trade of straw plaiting was very predominantly a female pursuit, while it provided extensive employment for young children of both sexes_-producing proportions of children

Table 2 Employment in the straw industry in Hertfordshire 1851

\begin{tabular}{|c|c|c|c|c|c|c|c|}
\hline \multirow[t]{2}{*}{ SRD } & \multicolumn{3}{|c|}{ Population } & \multirow{2}{*}{$\begin{array}{l}\text { Sex } \\
\text { ratio }\end{array}$} & \multicolumn{3}{|c|}{$\begin{array}{l}\text { Percentage of occupie } \\
\text { population in straw }\end{array}$} \\
\hline & Total & $\mathrm{M}$ & $\mathrm{F}$ & & All & $\mathrm{M}$ & $\mathrm{F}$ \\
\hline Berkhamsted & 11578 & 5487 & 6091 & 90 & 32 & 8 & 62 \\
\hline St Albans & 17991 & 8591 & 9400 & 91 & 24 & 4 & 49 \\
\hline Hemel Hempstead & 13094 & 6325 & 6769 & 93 & 29 & 8 & 59 \\
\hline Hitchin & 24519 & 12049 & 12470 & 97 & 22 & 4 & 56 \\
\hline Hatfield \& Welwyn & 8485 & 4332 & 4153 & 104 & 8 & 0 & 27 \\
\hline Royston & 14481 & 7375 & 7106 & 104 & 4 & 0 & 18 \\
\hline Watford & 18747 & 9232 & 9515 & 97 & 4 & 0 & 13 \\
\hline Hertford & 14517 & 7316 & 7201 & 102 & 2 & 0 & 8 \\
\hline Ware & 16445 & 8323 & 8122 & 102 & 0 & 0 & 1 \\
\hline Bishop's Stortford & 13401 & 6682 & 6719 & 99 & 0 & 0 & 1 \\
\hline Edmonton & 4815 & 2379 & 2436 & 98 & 0 & 0 & 1 \\
\hline Barnet & 5675 & 2902 & 2773 & 105 & 1 & 0 & 4 \\
\hline Hertfordshire & 163748 & 80993 & 82755 & 98 & 13 & 2 & 35 \\
\hline
\end{tabular}

Note: population totals include workhouses

employed in some localities that are as high as previously reported for any English parish studied to date. Table 2 shows the regional distribution of employment in the straw plait and hat trades, for the population as a whole and by sex. The concentration of the industry in the four SRDs that lay to the west and south-west of the county is immediately apparent, although this region extended east into parts of the Hatfield and Welwyn district, north into parts of Royston and south into parts of Watford, with lesser outposts in both Hertford and Barnet. The overwhelming predominance of 
females in the workforce is also quite clear from Table 2. Specific analysis of the employment of younger children (ages 5-9) of both sexes also reveals a concentration in Berkhamsted, St Albans, Hemel Hempstead and Hitchin, and the picture is similar for older girls (aged 10-14), while older boys tended to graduate to agricultural labour. Hence while Edwin Grey in his reminiscences of Harpenden (in the St Albans SRD) in the 1860s recorded that 'The children, both boys and girls, learned to plait when very young', and that even 'some of the men and the lads were also good at the work, doing it at odd times, or in the evening after farm work...', he adds that 'this home industry was always looked upon really as women's work', noting too that at the age of 9 or 10 boys began to take up employment with local farmers. ${ }^{25}$ Similarly, in 1867 it was reported from Toddington in Bedfordshire that 'At the age of 10 or 12 most of the boys exchange plaiting for farm work, but resume plaiting when severe weather or a scarcity of work prevents them from labouring in the fields. ${ }^{26}$

The straw plait and hat trades were by no means the prerogative of single women and girls. Analysis of female employment in the Berkhamsted, Hemel Hempstead and St Albans regions shows that while 57, 57 and 63 per cent respectively of occupied females aged 15 or over were employed in the industry, the proportions of married women remained substantial, at 35, 35 and 43 per cent respectively, figures which stand above those reported for many localities and regions more traditionally associated with the industrial employment of married women, such as Preston (26 per cent), Lancashire (30 per cent) and the Staffordshire potteries (14 per cent). ${ }^{27}$ Further breakdown by age in the St Albans SRD shows that there was little respite for women 
who remained single, with over 80 per cent recording an occupation in every decade of life through to their sixties. While there was a tendency for married women to withdraw from the workforce as they entered their thirties, this was only a difference of degree, and the proportion occupied remained at approximately 40 per cent until it fell to 36 per cent at age 60 and over. ${ }^{28}$

The straw industry in Hertfordshire, therefore, provided levels of employment for single and married women, and for children, on a scale rarely encountered anywhere in England: if such employment did indeed have an impact upon demographic behaviour, then one should expect to see it faithfully reflected here. Furthermore, the heavy regional concentration of the industry within the county allows clear demarcation of those registrar's districts where the industry was primarily situated from those where it was not, allowing cross-sectional comparison. Finally, as the industry waned from the 1870 s, temporal comparison can also be made to determine whether or not the contraction of these employment opportunities also impacted upon demographic behaviour.

\section{III}

In quantitative terms, female employment in the straw plait and hat trades in south and south-west Hertfordshire, among both single and married women, was clearly impressive, but the significance of these employment opportunities depends upon the level of earnings generated. Horrell and Humphries' recent analysis of 1,781 extant household budgets for 1787-1865 concluded that, except in the case of households 
headed by a male factory or outworker, both women's and children's contributions to family incomes were small throughout this period, while even in these more favoured occupational categories the contribution of women alone only approached one quarter in the period 1846-65 for factory workers, and more generally stood in the region of 5-12 per cent. ${ }^{29}$ Male earnings were crucial, children's earnings generally exceeded those of their mothers, and even when married women for whom earnings are separately identified are considered alone their contribution to family earnings for the various occupational categories across the same period ranged from just 11 to 21 per cent, and tended to fall with time. The authors conclude that 'In almost all the groups the contributions of married women were fading by mid century and had in any case never constituted much more than a taste of independence'. ${ }^{30}$

It is clear, however, as Horrell and Humphries emphasize, that 'account's of women's and children's contributions to family incomes must be conditional on their occupational and regional identity', and recent work on female employment has underlined the variety and complexity of occupational opportunities, chronologies, work patterns and levels and forms of remuneration, to create a veritable 'panorama of diversity, ${ }^{31}$ The great majority of the straw plaiters employed in Hertfordshire would fall within Horrell and Humphries' 'low-wage agriculture' category, within which women contributed just 9 per cent of household budgets across the period 1787-1865, while concentration upon married working women produces a total just a little higher at 13 per cent, but this provides no insight into the actual contribution of 
either single or married women in the straw plait and hat trades of south and southwest Hertfordshire, and how this might have changed over time. ${ }^{32}$

Unfortunately there are no extant wage series for female employment in straw plait or hatmaking upon which to draw, only scattered indications of earnings, while the regularity of employment both within and across years is also problematic. Fluctuations across time clearly did occur, and it is sometimes possible to identify periods of particular distress. The years $1832-4$ witnessed a slump in trade, as the respondents to the Poor Law Commission made clear: in St Peters parish in St Albans it was reported that the trade was 'very low', in Shenley 'very poor' and in Welwyn that it 'affords at present but a scanty subsistence'. ${ }^{33}$ Unsurprisingly, estimated earnings were low at this time, ranging from 1s. 6d. to 3s. 6d. per week in St Michaels, St Peters, Hemel Hempstead, Redbourn and Welwyn, though reaching as much as 6 or even 8 shillings per week in Watford where silk work was also available. ${ }^{34}$ Similarly in 1842 , when asked to explain the overcrowding in the Hitchin Union workhouse to the Medical Officer for Health, the Board of Guardians blamed 'a concurrence of want of employment among Mechanics and Agricultural Labourers through the wetness of the season, with a particular depression of the Straw Plait manufacture' ${ }^{35}$ These difficulties were not helped by the removal of protective tariffs in the same year and they continued into 1843, the Children's Employment Commission Report of that year noting that 'the earnings now of the plaiters were at least a third less than they were in former years', children being kept at home plaiting to avoid the cost of sending them to plaiting schools. Women, the report claimed, 
needed to work a 12-14 hour day to earn 3-4 shillings per week. ${ }^{36}$ Similarly, the reports from Bedfordshire and Buckinghamshire in 1867 of earnings as low as $2 \mathrm{~s} .6 \mathrm{~d}$. per week for plaiters over 16 years of age again reflect a period when the trade was 'unusually depressed'.

The straw plait trade was by no means alone in being affected by the trade cycle or the vicissitudes of the weather, however, and nor should these years of particular difficulty be taken as typical. Indeed, contemporaries may well have taken particular notice of both very high and very low earnings, and there is no justification for regarding the low figures reported for these years as typical any more than there is for regarding the excessive earnings reported by Arthur Young in some parishes during the Napoleonic Wars-as high as 42 shillings per week in one instance-as typical either. $^{38}$

Fortunately these various reports often indicate usual earnings during less depressed years, and there is also more objective evidence available. In 1831, for example, it was reported that although earnings at Hatfield, Hertfordshire, had fallen from their peak, they still stood at 8-10 shillings per week for women and 3-5 shillings for children, figures far higher than those given in $1834 .{ }^{39}$ In 1864 William Horley, postmaster and registrar for Toddington in Bedfordshire, reported earnings for most adult plaiters of $1 \mathrm{~s}$. per day when trade was good, 'though many will make more, up to 8 s. or 10 s., and some earn 12 s. a week' ${ }^{40}$ Similarly in 1867 George Culley reported for Bedfordshire and Buckinghamshire, 'on very good evidence' that, when the trade 
was good, plaiters from 16 years of age could earn 6-10 shillings per week. ${ }^{41} \mathrm{~A}$ particularly comprehensive account of the trade and potential earnings was provided in 1860 by A.J. Tanlsey, a Luton hat manufacturer, in an address to the Society of Arts. ${ }^{42}$ He reported earnings in straw plait for very young children of 1s.-1s. 6d, 2-3 s. at ages eight or nine, 4-5s. on leaving the plait schools, and as much as $7 \mathrm{~s}$. 'after they become skilful'. The earnings of a good, adult plaiter, after allowing for deduction of the cost of straws, would be from 5s.-7s. 6d. per week when trade was good, and hence 'a well ordered family will obtain as much or more than the husband who is at work on the neighbouring farm'- a view that is echoed in successive parliamentary reports as well as in reminiscences of the parish of Harpenden in the 1860 s written by Edwin Grey. ${ }^{43}$ Plaiting, however, was only one stage in the production process of straw hats, and bonnet sewing-largely an urban occupation, though only an important source of employment in Hertfordshire at St Albans-was regarded as a superior occupation as well as being better remunerated. Tansley reported that sewers engaged in 'sale work', the cheaper ranges, earned from 5-8s. per week, while the earnings of the more skilful 'room hands' were 'superior to any similar class in the kingdom', ranging from 8-12s. per week for 'medium' hands, to 16-20s. for 'the best fancy hands', although these earnings too would fluctuate according to the state of trade as well as with the season. J.E. White's report to the Children's Employment Commission of 1864, drawing upon evidence from Luton, similarly records 'remarkably good' wage for plait sewers, indifferent workers earning 10-12s, the best over 20s. per week, with an average of $18 \mathrm{~s}^{44}$ 
Although subject to periodic dislocation, earnings in the straw plait and hat trades whilst the industry continued to thrive were significant, particularly when compared with average earnings among male Hertfordshire agricultural labourers of 9-10s. per week. ${ }^{45}$ Some historians, however, have suggested that the trade was distinctly seasonal, raising the further crucial issue of the regularity of earnings, one discussion of the industry in north Essex suggesting that 'The demand for hats was confined to the summer and plait manufacture was a springtime activity, lasting for a maximum of three months'. ${ }^{46}$ Lucy Luck in her autobiography refers to the 'dull season', and reports 'the straw-work is very bad, as a rule, from July up to about Christmas', indicating a six-month season, but there is considerable contrary testimony. ${ }^{47}$ A.J. Tansley reported that "plait is made all year round, except during the interruption of harvest time'. ${ }^{48}$ Similarly Edwin Grey gives no suggestion of seasonality in Harpenden in the 1860s, describing women strolling in the lanes or plaiting in the fields in groups during the summer months. Only on market day, 'or at least the better part of it', was there a general cessation of plaiting, while gleaning appears to have taken priority over plaiting for a short time, 'though undoubtedly the stay-at-homes still kept on with their plait work'. ${ }^{49}$ In $1832-4$, a slack time for the industry, the Poor Law Commissioners noted that straw plaiting provided employment in Redbourn 'thoughout the year', and was particularly important in providing winter work in Shenley, Stevenage and Welwyn. ${ }^{50}$ In 1864 William Hardy of Toddington in Bedfordshire reported that while 'sewing work will not sell in summer... Plait, however, sells all year round', and George Philpotts' reported that his sewing room was busy 'From about Christmas until the end of May, and from August till 
November'. ${ }^{51}$ Messrs. Munt and Brown, straw bonnet and hat manufacturers of Luton, noted an exodus of female sewers from the town during July, only for them to return once again in August. ${ }^{52}$ Some specialized branches of the trade may have been more distinctly seasonal: in 1843 it was reported that fancy straw weaving at St Albans was 'only carried on for about two months of the year' but-equally instructive- 'the rest of the year they work at straw plait'. ${ }^{53}$ Contemporaries recognized the difference between summer plait and winter plait, the former being superior to the latter and commanding a higher price, but this in itself testifies to the fact that the trade continued all year round. ${ }^{54}$ Any seasonality, in employment or earnings, can only have represented a difference of degree, therefore, and does nothing to undermine the importance of the industry to the women of south and southwest Hertfordshire. Before the slump in earnings that accompanied the late-nineteenth century decline of the industry, therefore, potential earnings were clearly considerable enough to have impacted upon demographic behaviour.

It is unlikely, however, that these earnings were substantial enough to allow large numbers of young women to support themselves independently, particularly in view of the periodic downturns the trade suffered, and this judgement is largely supported by detailed analysis of household composition in some of the key straw plait and hatmaking areas. Although contemporaries offered a range of views on the issue-some suggesting that these employment opportunities encouraged girls to leave home at an early age and others suggesting the opposite effect-neither in the Berkhamsted SRD nor in the St Albans SRD in 1851 (where bonnet sewing might 
have provided even more opportunity) is there much evidence of early female independence. $^{55}$

To take the example of the St Albans SRD, out of a total population of 10,763 in the rural parts of the region, just 11 of the 497 female teenage straw plaiters (2.2\%) were lodging in households to which they were apparently unrelated. These were the only female teenage lodgers, and constituted $1.0 \%$ of the age group. Among those in their 20s working in the straw plait and hat trades, just 8 out of 390 straw plait and hat workers were unmarried and heading their own households $(2.1 \%)-6$ straw plaiters and 2 bonnet makers-which compares with 13 out of $795(1.6 \%)$ among the population at large. In the town of St Albans, with a total population excluding the workhouse of $6,985,359$ teenage girls worked in the straw, straw hat or Brazilian hat trades, and of these $12(3.3 \%)$ were lodgers apparently living apart from their kin, while just 4 hat workers headed their own independent households. ${ }^{56}$ In all in the town there were 19 lodgers in this age group, constituting $2.5 \%$ of the total. Of those in their 20s, 15 unmarried women straw and hat workers headed their own households (11 hat makers, 2 Brazilian hat makers, one bonnet sewer and one straw plaiter) out of a total of 221 women in this age group working in the industry (6.8 per cent), which compares to 27 out of 708 ( 3.8 per cent) for the age group as a whole. These are larger number than those found in the Bishop's Stortford district to the east, where the straw industry was virtually non-existent. Here, in the rural parishes (total population 8,144), just 6 of 779 females aged 10-19 were unrelated lodgers $(0.8 \%)$, while only 6 out of 597 women in their twenties were unmarried household heads $(1.0 \%)$. In the 
town of Bishop's Stortford (population 4,942), perhaps surprisingly, there were even fewer teenage lodgers, just 3 out of $556(0.5 \%)$, while 7 of the 407 women in their twenties were unmarried household heads (1.7\%). Opportunities for early female independence were therefore more considerable in the key straw plait and hat areas than elsewhere in the county, both in town and in countryside, but even here the numbers are small. In the rural areas where plaiting dominated, the industry does not appear to have created significant opportunities for young women to establish their independence. In the town of St Albans the superior earnings available to hatmakers produced greater opportunities, but even here the number taking advantage of this was relatively small, while urban women generally were more likely than their rural counterparts to establish their independence in early adulthood. Female earnings in the straw plait and hat trades, therefore, were probably far more important as a contribution to the household economy than they were as a means to establish female independence. It is to the more general impact of the industry upon population growth, migration and marriage that we can now turn.

IV

The broad pattern of population growth in nineteenth-century Hertfordshire is shown in Table 3 . The county grew by 159 per cent across the century, considerably below the national growth rate (England and Wales) of 266 per cent. ${ }^{57}$ As in England and Wales as a whole, growth was generally fastest in the earlier decades of the century, the total growing by 72 per cent $1801-51$ and 51 per cent $1851-1901$. At the start of 
the century Hertfordshire accounted for 1.10 per cent of the national total, its slower rate of growth producing a reduction in its share in every decade except the 1890s,

Table 3 Hertfordshire population 1801-1901 by SRD (ancient county)

\begin{tabular}{|c|c|c|c|c|c|c|c|c|c|c|c|}
\hline SRD & 1801 & 1811 & 1821 & 1831 & 1841 & 1851 & 1861 & 1871 & 1881 & 1891 & 1901 \\
\hline $\begin{array}{l}\text { Berkhamsted } \\
\% \text { arowth }\end{array}$ & 5886 & 6982 & 8420 & $\begin{array}{r}8866 \\
51\end{array}$ & 10519 & $\begin{array}{r}11503 \\
95\end{array}$ & $\begin{array}{r}12074 \\
105\end{array}$ & 12923 & 14092 & 14827 & $\begin{array}{r}15013 \\
155\end{array}$ \\
\hline $\begin{array}{l}\text { \% growth } \\
\text { St Albans }\end{array}$ & 9834 & $\begin{array}{r}19 \\
11214\end{array}$ & $\begin{array}{r}43 \\
14114\end{array}$ & $\begin{array}{r}51 \\
15833\end{array}$ & $\begin{array}{r}79 \\
17048\end{array}$ & $\begin{array}{r}95 \\
18004\end{array}$ & $\begin{array}{r}105 \\
18926\end{array}$ & $\begin{array}{r}120 \\
21079\end{array}$ & $\begin{array}{r}139 \\
23296\end{array}$ & $\begin{array}{r}152 \\
26872\end{array}$ & $\begin{array}{r}155 \\
33008\end{array}$ \\
\hline$\%$ growth & & 14 & 44 & 61 & 73 & 83 & 92 & 114 & 137 & 173 & 236 \\
\hline Hemel I & 6462 & 7476 & 8923 & 9910 & 11498 & 13120 & 13922 & 14706 & 1460 & 15116 & 16481 \\
\hline$\%$ grov & & 16 & 38 & 53 & 78 & 103 & 115 & 128 & 126 & 134 & 155 \\
\hline Hitchin & 13453 & 14905 & 18198 & 20472 & 22164 & 24540 & 25412 & 27469 & 27202 & 27303 & 28505 \\
\hline$\%$ growth & & 11 & 35 & 52 & 65 & 82 & 89 & 104 & 102 & 103 & 112 \\
\hline Hatfiel & 5741 & 6351 & 7267 & 7903 & 8019 & 8499 & 8400 & 8631 & 8802 & 9309 & 9816 \\
\hline$\% \mathrm{gr}$ & & 11 & 27 & 38 & 40 & 48 & 46 & 50 & 53 & 62 & 71 \\
\hline Royston & 9355 & 10076 & 11667 & 12242 & 13633 & 13988 & 13397 & 13353 & 12396 & 11752 & 10393 \\
\hline$\%$ growth & & 8 & 25 & 31 & 46 & 50 & 43 & 43 & 33 & 26 & 11 \\
\hline Watford & 10003 & 11306 & 13689 & 15379 & 18009 & 18800 & 20355 & 27172 & 31328 & 38914 & 53936 \\
\hline$\%$ growth & & 13 & 37 & 54 & 80 & 88 & 103 & 172 & 213 & 289 & 439 \\
\hline Hertford & 9452 & 9981 & 11838 & 13364 & 14145 & 15090 & 15301 & 16009 & 16754 & 17196 & 17029 \\
\hline$\% \mathrm{gr}$ & & 6 & 25 & 41 & 50 & 60 & 62 & 69 & 77 & 82 & 80 \\
\hline Ware & 11092 & 11995 & 13494 & 14654 & 15504 & 16482 & 16515 & 17460 & 18625 & 19603 & 21156 \\
\hline$\% g r$ & & 8 & 22 & 32 & 40 & 49 & 49 & 57 & 68 & 77 & 91 \\
\hline Bishor & 8301 & 8960 & 10630 & 11694 & 12805 & 13433 & 13427 & 14528 & 14938 & 14609 & 14610 \\
\hline & & 8 & 28 & 41 & 54 & 62 & 62 & 75 & 80 & 76 & 76 \\
\hline Edmonton & 3173 & 3598 & 4376 & 5021 & 5402 & 5579 & 6592 & 7518 & 7735 & 9620 & 12292 \\
\hline$\% g$ & & 13 & 38 & 58 & 70 & 76 & 108 & 137 & 144 & 203 & 287 \\
\hline Barnet & 3172 & 3946 & 4583 & 5366 & 5541 & 5697 & 6556 & 9127 & 11321 & 13165 & 16183 \\
\hline \% growth & & 24 & 44 & 69 & 75 & 80 & 107 & 188 & 257 & 315 & 410 \\
\hline Hertfordshire & 95924 & 106790 & 127199 & 140704 & 154287 & 164735 & 170877 & 89975 & 201095 & 218286 & 248422 \\
\hline \% growth & & 11 & 33 & 47 & 61 & 72 & 78 & 98 & 110 & 128 & 159 \\
\hline
\end{tabular}

Note: these figures are taken from printed census data, and the 1851 figures differ slightly from the calculations from census enumerators' books used in Tables 2 above and 8 below.

until by 1901 it accounted for just 0.77 per cent. Table 3 shows distinct intra-county variations, however, and two key features in particular. First, there was considerable growth in those SRDs that lay to the extreme south of the county - Watford, 
Edmonton and Barnet-particularly towards the end of the century as the suburbanization of London gathered pace and cheap transport incorporated these areas more fully into London's orbit. Second, until at least 1851 the SRDs which incorporated the straw plait districts grew faster than all of the other districts except for those on the London fringes, producing a clear contrast in rates of growth between Berkhamsted, St Albans, Hemel Hempstead and Hitchin on the one hand, and Hatfield, Royston, Hertford, Ware and Bishops Stortford on the other. Furthermore, in three of these four districts (Berkhamsted, Hemel Hempstead and Hitchin) growth slowed considerably after 1871 , coinciding with the onset of the decline of the straw plait trade.

More detailed analysis by parish and period qualifies this conclusion. Table 4 presents summary results of growth rates for straw and non-straw areas, using population data collected for each parish from the printed census returns, and occupational structures calculated for 151 parishes or sub-parishes from the census enumerators' books for 1851. To allow for potential distortion produced by the rapid growth of areas close to London, and the spectacular late-nineteenth century growth of Watford, the data are presented for the county as a whole, as well as with these districts excluded from the totals. The relatively rapid growth of the straw plait and hat areas of the county in the first half of the century is confirmed, but during the next 20 years growth was slightly slower than in the rest of the county, only proceeding at the same rate if Barnet and Edmonton are removed from the equation, and only exceeding the 
non-straw areas if Watford is removed too. Thereafter, as the straw industry waned, growth was slower in the declining straw areas than in the remainder of the county,

Table 4 Rates of population growth in straw and non-straw regions of Hertfordshire 1801-1901

\begin{tabular}{llccccc}
\hline & & $1801-1901$ & $1801-1851$ & $1851-1901$ & $1851-1871$ & $1871-1901$ \\
\cline { 3 - 5 } County of Herts & & & & & \\
& Straw & 152 & 85 & 36 & 13 & 21 \\
& Non-Straw & 164 & 62 & 63 & 17 & 39 \\
& Total & 159 & 72 & 51 & 15 & 31 \\
Excluding Edmonton & Straw & 152 & 85 & 36 & 13 & 21 \\
\& Barnet & Non-straw & 140 & 60 & 50 & 13 & 33 \\
& Total & 146 & 71 & 43 & 13 & 27 \\
Excluding Edmonton, & Straw & 152 & 84 & 36 & 13 & 21 \\
Barnet \& Watford & Non-straw & 105 & 57 & 30 & 10 & 18 \\
& Total & 126 & 70 & 33 & 12 & 19 \\
& & & & & & \\
\hline
\end{tabular}

though again the exclusion of those parishes on the London fringes restores just a small advantage. In the first half of the nineteenth century, therefore, the straw areas exhibited relatively rapid growth, while after mid-century that advantage was lost, and towards its end growth proceeded only slowly as the industry waned, and as new and more dynamic areas emerged on the fringes of the capital.

How this growth was achieved is difficult to determine before the start of civil registration in 1837. Nine Hertfordshire parishes are included amongst the 404 employed by the Cambridge Group for the History of Population and Social Structure, and data survives for seven of these for the early nineteenth century. ${ }^{58}$ Four are straw 
plait parishes (Great Berkhamsted, Northchurch, Hemel Hempstead and Hitchin) and three are not (Aldenham, Barley and Hunsdon). All experienced natural increase across the period, the seven as a whole exhibiting a baptism-burial ratio of 1.57 for 1801-37, with figures for straw and non-straw parishes respectively standing at 1.55 and 1.64. Comparison of the natural increase achieved across the first three decades of the century with population growth as indicated by the census returns tells a different story, however. The four straw parishes produced a natural surplus of 3,461 , but grew by 5,187 ; the three non-straw parishes produced a surplus of 952 , but grew by just 624. The temptation is to conclude that the straw parishes were attracting immigrants, the non-straw parishes experiencing net emigration. However, not only are the samples very small, particularly for non-straw parishes, but the impact of nonconformity, delay between birth and baptism and residual under-registration upon these figures by the start of the nineteenth century is estimated to have been considerable, and as our straw sample includes three market towns they may well have been particularly severely affected. The application of correction factors of the order applied by the Cambridge Group to their data for these years (between 1.3848 and 1.4793 for baptisms and 1.3393 to 1.4878 for burials) would effectively wipe out the apparent contribution of immigration to the growth achieved by the four straw parishes, although it would not remove the contrast between these and the non-straw group, and it remains possible — indeed likely — that sex selective immigration was occurring, a subject we will return to below. ${ }^{59}$ 
From the start of civil registration in 1837 to 1900 Hertfordshire's population grew by natural increase, the surplus of births over deaths 1841-1900 amounting to 141,274, with every decade adding over $20,000 .{ }^{60}$ Calculations of nine-year averages centred upon 1851, 1871 and 1891 produces mean crude birth rates (per 1,000 of the

Table 5a Population growth and natural increase in Hertfordshire 1851-1871

\begin{tabular}{|c|c|c|c|c|c|}
\hline & \multicolumn{2}{|c|}{ Population Growth } & \multirow{2}{*}{$\begin{array}{c}\text { Natural } \\
\text { increase }\end{array}$} & \multirow{2}{*}{$\begin{array}{c}\text { Net } \\
\text { migration }\end{array}$} & \multirow{2}{*}{$\begin{array}{c}\text { Natural increase } \\
\text { lost by migration } \\
(\%)\end{array}$} \\
\hline & No. & $\%$ & & & \\
\hline Hertfordshire & 20650 & 12 & 46271 & -25621 & 55 \\
\hline Straw RDs & 9499 & 12 & 21404 & -11905 & 56 \\
\hline Non-straw RDs & 11151 & 12 & 24867 & -13716 & 55 \\
\hline
\end{tabular}

Table 5b Population growth and natural increase in Hertfordshire 1871-1901

\begin{tabular}{lccccc}
\hline & & & & Population Growth \\
& No. & $\%$ & Natural & Net & $\begin{array}{c}\text { Natural increase } \\
\text { lost by migration } \\
(\%)\end{array}$ \\
Hertfordshire & 45148 & 23 & 74612 & -29464 & 39 \\
Straw RDs & 19609 & 23 & 37302 & -17693 & 47 \\
Non-straw RDs & 25539 & 24 & 37310 & -11771 & 32
\end{tabular}

Source: Annual Reports of the Registrar General for Births, Marriages and Deaths.

population) of 32, 32 and 27 respectively, and crude death rates of 20, 19 and 16, both sets of figures standing slightly below the national average, and producing a net surplus just a little below the national figure. ${ }^{61}$ Comparison of inter-censal population changes with surpluses of baptisms over burials indicate that Hertfordshire was an 
exporter of population, net emigration standing at 63,908 1841-1901, and accounting for 45 per cent of the natural growth achieved in that period. Comparison between straw and non-straw areas of the county confirms the impression given by raw population totals. As Tables 5a and 5b show, in the sub-period 1851-71 the straw and non-straw regions exhibited almost identical figures for the proportion of their population lost by net migration, but with the waning of the straw industry towards the end of the century a clear contrast emerged, until by 1871-1901 the straw areas lost 47 per cent of their natural increase through net migration, the non-straw areas just 32 per cent.

While Hertfordshire was a net exporter of population, there are clear indications that migration was sex-selective. The sex ratios of the respective SRDs presented in Table 2 above reveal particularly low figures for three of the four straw districts (Berkhamsted 90, St Albans 91 and Hemel Hempstead 93), while that for Hitchin stood just a little below the county average at 97 (96 excluding the workhouse). The issue of sex-selective migration can be further explored through examination of proportions migrant by gender as revealed in the digitized 1851 census returns and the sex ratios they reveal among young adults - the age group with the greatest propensity to migrate. Table 6 presents this data for the rural parishes in the St Albans and Berkhamsted districts, where the straw trades were particularly prevalent, for the top 15 straw parishes in the county and for the rural parts of the Bishop's Stortford and Royston districts, the two most wholly agricultural districts in the county. All major towns are omitted, to remove any possible overriding urban influence, notably the 
prevalence here of domestic service and service trades that also provided female employment opportunities.

Table 6 Sex ratios and lifetime migration to selected rural Hertfordshire parishes males and females ages 15-34

\begin{tabular}{|c|c|c|c|c|c|c|c|c|c|}
\hline \multirow[b]{2}{*}{ Straw areas } & \multirow[t]{2}{*}{ Age } & \multicolumn{3}{|c|}{ Population } & \multirow{2}{*}{$\begin{array}{l}\text { Sex } \\
\text { ratio }\end{array}$} & \multicolumn{2}{|c|}{$\begin{array}{c}\text { Male } \\
\text { migrants }\end{array}$} & \multicolumn{2}{|c|}{$\begin{array}{l}\text { Female } \\
\text { migrants }\end{array}$} \\
\hline & & Total & $\mathrm{M}$ & $\mathrm{F}$ & & No. & $\%$ & No. & $\%$ \\
\hline \multirow[t]{2}{*}{ St Albans SRD rural } & $15-24$ & 1193 & 535 & 658 & 81 & 223 & 42 & 267 & 41 \\
\hline & $25-34$ & 893 & 401 & 492 & 82 & 214 & 53 & 226 & 46 \\
\hline \multirow{2}{*}{ Berkhamsted SRD rural } & $15-24$ & 1559 & 721 & 838 & 86 & 307 & 43 & 426 & 51 \\
\hline & $25-34$ & 1163 & 533 & 630 & 85 & 289 & 54 & 357 & 57 \\
\hline \multirow[t]{2}{*}{ Top 15 straw parishes } & $15-24$ & 2761 & 1289 & 1472 & 88 & 499 & 39 & 571 & 39 \\
\hline & $25-34$ & 2035 & 939 & 1096 & 86 & 468 & 50 & 547 & 50 \\
\hline
\end{tabular}

Non-straw areas

$\begin{array}{lccccccccc}\text { Bishops Stort SRD rural } & 15-24 & 1397 & 765 & 632 & 121 & 193 & 25 & 288 & 46 \\ & 25-34 & 1104 & 556 & 548 & 101 & 208 & 37 & 287 & 52 \\ \text { Royston SRD rural } & & & & & & & & & \\ & 15-24 & 1742 & 1001 & 741 & 135 & 253 & 25 & 382 & 52 \\ & 25-34 & 1235 & 608 & 627 & 97 & 257 & 42 & 374 & 60\end{array}$

Notes: SRDs exclude the four major towns of St Albans, Berkhamsted, Bishop's Stortford and Royston.

St Albans SRD excludes the hinterland of St Albans where place of birth in confused by the use of names of hamlets, parishes and the town itself.

Royston SRD excludes the 3 villages where straw plaiting had a presence: Ashwell, Hinxworth and Sandon.

Numbers migrant represent the combined total of non-natives identified in individual parishes, not incomers to the region taken as a whole.

Top 15 straw parishes include all those where the straw industry accounted for $75 \%$ or more of female employment. 
The proportion of local populations identified in census returns as migrant is often employed as a measure of the ability of a town or parish to attract immigrants, and hence of its attractiveness to outsiders. ${ }^{62}$ If this were a valid procedure, then the data in Table 6 would indicate that young female adults were no more attracted to Hertfordshire parishes where the straw industry prevailed than they were to parishes where it was wholly absent: indeed, if anything the opposite was true. This procedure is not, however, valid. The proportions migrant revealed in a census represent the combined impact of two tendencies, the ability of a parish to retain its population and its ability to attract incomers, and while both tendencies reflect the opportunities a parish had to offer they impact in opposite ways upon the proportions native or migrant as revealed in the census. Retention of the indigenous population inevitably reduces the proportional impact of a given number of migrants, and vice versa, and hence an 'attractive' parish can exhibit a lower proportion of immigrants than an 'unattractive' parish. $^{63}$

Of much greater significance, therefore, is the sex ratio that results from the combined influence of population retention and immigration. ${ }^{64}$ Table 6 reveals a stark contrast between the straw and non-straw parishes. In the straw areas the sex ratio among the age group with the highest propensity to migrate, $15-24$, stood as low as 81 in the $\mathrm{St}$ Albans region and 86 in Berkhamsted, while in Bishop's Stortford it stood at 121 and in Royston 135. In the age group 25-34 the ratio remained low in the straw areas (8285), and fell considerably in the non-straw districts while still remaining substantially higher (97-101). Figures calculated for the top 15 straw parishes across the county 
stood at similar levels to those found in the St Albans and Berkhamsted districts. This considerable skew towards women prevailed despite the fact that female children and young women in Victorian England experienced higher age-specific mortality than male children and young men, that this discrepancy was particularly marked in rural

Table 7 Sex ratios in Hertfordshire 1851, 1871 and 1891, ages 15-34

\begin{tabular}{|c|c|c|c|c|c|c|c|c|}
\hline \multirow[b]{2}{*}{ Straw areas } & \multicolumn{4}{|c|}{$15-24$} & \multicolumn{4}{|c|}{$25-34$} \\
\hline & All & M & $\mathrm{F}$ & $\begin{array}{l}\text { Sex } \\
\text { ratio }\end{array}$ & All & $\mathrm{M}$ & $\mathrm{F}$ & $\begin{array}{l}\text { Sex } \\
\text { ratio }\end{array}$ \\
\hline 1851 straw SRDs & 12861 & 6086 & 6775 & 90 & 9963 & 4631 & 5332 & 87 \\
\hline 1871 straw SRDs & 13968 & 6402 & 7566 & 85 & 10615 & 4606 & 6009 & 77 \\
\hline 1891 straw SRDs & 14768 & 7114 & 7654 & 93 & 11062 & 4930 & 6132 & 80 \\
\hline 1851 rural straw RDs & 5687 & 2882 & 2805 & 103 & 4429 & 2164 & 2265 & 96 \\
\hline 1871 rural straw RDs & 5757 & 2728 & 3029 & 90 & 4214 & 1915 & 2299 & 83 \\
\hline 1891 rural straw sanitary districts & 9109 & 4543 & 4566 & 100 & 6846 & 3072 & 3774 & 81 \\
\hline 1851 top 15 straw parishes (1851) & 2761 & 1289 & 1472 & 88 & 2035 & 939 & 1096 & 86 \\
\hline 1891 top 15 straw parishes (1891) & 2825 & 1389 & 1436 & 97 & 2131 & 928 & 1203 & 77 \\
\hline \multicolumn{9}{|l|}{ Non-straw areas } \\
\hline 1851 non-straw SRDs & 19169 & 10178 & 8991 & 113 & 14641 & 7224 & 7417 & 97 \\
\hline 1871 non-straw SRDs & 19975 & 10434 & 9541 & 109 & 15330 & 7405 & 7925 & 93 \\
\hline 1891 non-straw SRDs & 22276 & 11617 & 10659 & 109 & 17012 & 8122 & 8890 & 91 \\
\hline 1851 rural non-straw RDs & 11994 & 6471 & 5523 & 117 & 8965 & 4465 & 4500 & 99 \\
\hline 1871 rural non-straw RDs & 11528 & 6236 & 5292 & 118 & 8786 & 4254 & 4532 & 94 \\
\hline 1891 rural non-straw sanitary districts & 14850 & 7906 & 6944 & 114 & 11318 & 5414 & 5904 & 92 \\
\hline \multicolumn{9}{|l|}{ Hertfordshire } \\
\hline 1851 registration county & 32030 & 16264 & 15766 & 103 & 24604 & 11855 & 12749 & 93 \\
\hline 1871 registration county & 33943 & 16836 & 17107 & 98 & 25945 & 12011 & 13934 & 86 \\
\hline 1891 registration county & 37044 & 18731 & 18313 & 102 & 28074 & 13052 & 15022 & 87 \\
\hline
\end{tabular}

Note: RDs are registration districts, often referred to as registration sub-districts. In the registration county of Hertfordshire there were 28 of these, in 10 SRDs. 
areas, and was commonly associated with high levels of pthisis mortality. ${ }^{65}$ Given that in 1860 and 1861 the Medical Officer for Health presented data showing high levels of death from pulmonary diseases in the Berkhamsted SRD, and much higher levels for females than for males, the sex ratios found here are all the more remarkable. ${ }^{66}$ It is clear, therefore, that in 1851 net migration among young adults to rural straw plait parishes was collectively substantially favourable to females, while in the agricultural parishes where straw plait had no presence it was heavily favourable to males.

How this changed with the continued expansion of the straw industry through to 1871 and its subsequent contraction is difficult to establish in the absence of digitized census information for later dates, the only consistent data on age and sex structure between 1851 and 1891 in the published census reports relating to SRDs, which prevent precise demarcation of straw regions and also complicate the analysis through their incorporation of towns. Nevertheless, Table 7 offers analysis by SRD from the published reports, by RDs for 1851 and 1871 and, in the absence of a more satisfactory breakdown, makes use of the demarcation of urban and rural sanitary districts for 1891. Also presented are calculations from the census enumerators' books for the same 15 parishes that featured in Table 6 - those leading the way in terms of female employment in the straw industry in 1851 .

At the level of the SRD the skew towards females in straw regions in the age group with the greatest propensity to migrate, $15-24$, is again clear, in contrast to the skew towards men in non-straw SRDs, the discrepancy continuing into the age group 25-34 
in a less exaggerated fashion. When rural straw RDs are isolated the discrepancy remains, though the female skew is less marked in both age groups. The figure of 103 for 1851 stands out, and contrasts with the data for the rural parts of the St Albans and Berkhamsted SRDs shown in Table 6. In part it is a product of the fact that the data in Table 6 reflect the situation in the most concentrated straw plaiting area of the county, but much of the discrepancy is due to the remarkable skew towards men found in the Hatfield RD—far more marginally a straw plait area—where the sex ratio at ages 1524 stood as high as 142 . If Hatfield is removed from the equation, the figure for rural straw RDs collectively falls to 94 .

In terms of change over time the data for the straw areas for the age group 15-24, whichever classification is employed, follows a path that could have been predicted from the rise and decline of the straw industry: sex ratios become increasingly skewed towards women as it rose to its height in 1871, and become more balanced by 1891 when the industry was in decline. On the assumption that these ratios are heavily influenced by the behaviour of the female population, the ability of parishes to retain or attract young women increased to 1871 , and had declined by $1891{ }^{67}$ In the age group 25-34, however, the pattern is less predictable, for sex ratios in the straw areas fell to 1871 and remained low 20 years later. The following section will consider how these trends may have impacted upon marriage patterns. 
The impact of female employment opportunities on marriage patterns has been central to discussions of the relationship between cottage industry and demography since they began, and remains an unresolved issue. The digitized 1851 census data for Hertfordshire provides an ideal opportunity to test the relationship, allowing detailed occupational analysis of individual parishes and chapelries to be set alongside

Table 8 Singulate mean age at marriage of women in Hertfordshire 1851

\begin{tabular}{|c|c|c|c|c|c|}
\hline \multirow[t]{2}{*}{ District } & \multicolumn{3}{|c|}{ Population } & \multirow{2}{*}{$\begin{array}{l}\text { Sex } \\
\text { ratio }\end{array}$} & \multirow{2}{*}{$\begin{array}{l}\text { Singulate mean } \\
\text { age at marriage }\end{array}$} \\
\hline & Total & Male & Female & & \\
\hline Berkhamsted SRD & 11517 & 5448 & 6069 & 90 & 25.97 \\
\hline St Albans SRD & 17748 & 8454 & 9294 & 91 & 26.63 \\
\hline Hemel Hempstead SRD & 12985 & 6251 & 6734 & 93 & 26.38 \\
\hline Hitchin SRD & 24345 & 11930 & 12415 & 96 & 25.51 \\
\hline Hatfield/Welwyn SRD & 8358 & 4256 & 4102 & 104 & 26.76 \\
\hline Hertford SRD & 14400 & 7248 & 7152 & 101 & 26.15 \\
\hline Royston SRD & 14326 & 7284 & 7042 & 103 & 25.16 \\
\hline Watford SRD & 18491 & 9076 & 9415 & 96 & 26.32 \\
\hline Ware SRD & 16318 & 8258 & 8060 & 102 & 25.28 \\
\hline Bishops Stortford SRD & 13074 & 6500 & 6574 & 99 & 24.85 \\
\hline Edmonton SRD & 4815 & 2379 & 2436 & 98 & 27.49 \\
\hline Barnet SRD & 5530 & 2819 & 2711 & 104 & 28.16 \\
\hline Straw parishes & 76541 & 37181 & 39360 & 94 & 26.02 \\
\hline Non-straw parishes & 85366 & 42722 & 42644 & 100 & 26.02 \\
\hline Top 15 straw parishes & 14972 & 7263 & 7709 & 94 & 25.16 \\
\hline Rural straw parishes & 52886 & 26269 & 26617 & 99 & 25.48 \\
\hline Rural non-straw parishes & 64460 & 32490 & 31970 & 102 & 26.06 \\
\hline Urban areas & 44561 & 21145 & 23416 & 90 & 26.51 \\
\hline Rural areas & 117346 & 58758 & 58588 & 100 & 25.79 \\
\hline Hertfordshire & 161907 & 79903 & 82004 & 97 & 26.01 \\
\hline \multicolumn{6}{|c|}{$\begin{array}{l}\text { Notes: Top } 15 \text { straw parishes include all those where the straw industry accounted for } 75 \% \text { or } \\
\text { more of female employment. }\end{array}$} \\
\hline
\end{tabular}


calculation of the singulate mean age at marriage (SMAM) ${ }^{68}$ The results of this analysis for women are presented in Table 8, which distinguishes the respective SRDs as well as providing a breakdown between straw and non-straw parishes and urban and rural areas. The figure for the county of Hertfordshire stands only marginally above that for England and Wales in 1851 (26.01 compared to 25.77), and also above that for the female population of Essex $(25.23) .{ }^{69}$ Comparison of the collective experience of all those parishes where the straw industry was prominent with those where it was not, however-while confirming the impact of the straw industry on the sex ratio-reveals no difference at all in estimated age at marriage. In the Berkhamsted district, where the proportion of the occupied female population working in the straw industry was highest (61.5 per cent), the SMAM for women stood just 0.04 years below county average, while in Bishops Stortford where the industry was almost entirely absent, female marriage took place more than a year earlier. The differences are relatively small, but there is no clear and consistent relationship by SRD between levels of straw industry employment and average age at marriage.

Analysis at the level of the parish rather than the SRD qualifies this conclusion, allowing comparison between straw and non-straw parishes in rural areas only, as well as examination of those parishes where the industry was particularly heavily concentrated. Exclusion of the urban influence makes a difference, for now the rural straw parishes emerge with a lower SMAM by a small margin of 0.58 years. ${ }^{70}$ The experience of those 15 parishes in the county where the straw industry was most 
heavily concentrated, accounting for fully 75 per cent or more of total female employment, underlines the industry's influence. In these parishes collectively, the SMAM stood at 25.16, approaching a full year earlier than the county average. The data in Table 8, therefore, would appear to suggest that in rural straw areas generally—despite their significantly lower sex ratios - there was a tendency for women to marry earlier on average, and this was even more marked in those parishes with particularly heavy concentrations of straw industry employment. These were, however, tendencies only, as the application of a non-parametric Mann-Whitney Utest to the results confirm. Comparison of the distribution of SMAM scores between all straw and non-straw parishes produces an $18.7 \%$ probability of a random distribution, as one might expect from the results presented in Table 8 . This falls to $6.9 \%$ when urban parishes are removed from the equation, but only when urban parishes are compared to rural ones are the results statistically significant, at $4.1 \%$. These results are not surprising, for calculation of the singulate mean age at marriage is not well suited to small, individual parishes, where chance events can easily produce aberrant scores and hence impact upon any distribution being tested. Furthermore, marriage choices, while generally geographically circumscribed, were not confined within parish boundaries, and hence it is encouraging that more confidence can be placed in comparison of rural straw and non-straw parishes, where the collective experience of groups of contiguous parishes are being compared.

Two other features stand out from Table 8 . The first is the higher age at female marriage found in the small towns of Hertfordshire compared with rural areas, 
producing as we have seen a statistically significant difference in distribution of

SMAM scores, and this was no doubt the product of the combined impact of the

skewed sex ratio produced by sex-selective immigration alongside high levels of

domestic service. The second is the even higher figures for the two SRDs which stood

on the fringes of London, Edmonton and Barnet, where again the impact of

Table 9 Singulate mean age at marriage in Hertfordshire, 1851 and 1891

\begin{tabular}{|c|c|c|c|c|c|}
\hline \multirow[t]{2}{*}{ District } & \multicolumn{3}{|c|}{ Population } & \multirow{2}{*}{$\begin{array}{l}\text { Sex } \\
\text { ratio }\end{array}$} & \multirow{2}{*}{$\begin{array}{l}\text { Singulate mean } \\
\text { age at marriage }\end{array}$} \\
\hline & Total & Male & Female & & \\
\hline Berkhamsted SRD 1851 & 11517 & 5448 & 6069 & 90 & 25.97 \\
\hline Berkhamsted SRD 1891 & 14367 & 6887 & 7480 & 92 & 26.96 \\
\hline Berkhamsted rural 1851 & 8650 & 4118 & 4532 & 91 & 24.84 \\
\hline Berkhamsted rural 1891 & 8233 & 3932 & 4301 & 91 & 26.86 \\
\hline St Albans rural 1851 & 6831 & 3285 & 3546 & 93 & 25.19 \\
\hline St Albans rural 1891 & 9769 & 4698 & 5071 & 93 & 26.46 \\
\hline 1851 top 15 straw parishes & 14972 & 7263 & 7709 & 94 & 25.16 \\
\hline 1891 same 15 parishes & 16872 & 8032 & 8840 & 91 & 26.68 \\
\hline Hertfordshire 1851 (1) & 167127 & 82580 & 84547 & 98 & 26.01 \\
\hline Hertfordshire 1851 (2) & 173962 & 86465 & 87497 & 99 & 25.22 \\
\hline Hertfordshire 1891 (2) & 215179 & 104525 & 110654 & 94 & 25.97 \\
\hline \multicolumn{6}{|c|}{$\begin{array}{l}\text { Notes: Hertfordshire } 1851 \text { (1) is for the ancient county, and is calculated using five year averages up to } \\
\text { age } 49 \text { (as is conventional) from each individual enumeration district. Hertfordshire } 1851 \text { (2) and } \\
\text { Hertfordshire } 1891 \text { (2) relate to the registration county, and are calculated using ten year averages from } \\
\text { the } 1851 \text { and } 1891 \text { census reports (BPP } 1852-3 \text {, LXXXVIII Pt } 1, \text { p. } 147 \text { and BPP 1893-4, CVI, III, p. 96) up } \\
\text { to age } 44 \text {, as employed by Wrigley and Schofield in The population history of England, p. } 437 \text { (for } \\
\text { comparability, because data is only available by ten year periods in } 1891 \text { ). The difference in the two } \\
\text { Hertfordshire figures for } 1851 \text { is partly due to the geographical mis-match between ancient and registration } \\
\text { county, but mainly because the exclusion of years of singleness from } 45-49 \text { in the second calculation } \\
\text { serves to reduce the SMAM. If the figure for the registration county is re-calculated using five-years } \\
\text { periods up to age } 49 \text {, the SMAM rises to } 25.78 \text {, much closer to the figure produced for the ancient county. }\end{array}$} \\
\hline
\end{tabular}


employment in the domestic service sector was making itself felt. Immigration of young adults inevitably impacts upon the SMAM, and the higher figures revealed for these areas confirms their attractiveness to immigrants.

In Table 9 the SMAM for the Berkhamsted SRD and the rural parts of the St Albans SRD are compared for 1851, when the straw industry was thriving, with the figures for 1891 , by which time it had declined significantly, while the experience of the same 15 parishes included in Table 8 with particularly heavy concentrations of straw industry employment in 1851 are also compared across the period. Between 1851 and 1891 the SMAM for the Berkhamsted SRD rose by almost exactly one year (0.99) as the straw industry declined, providing prima facie support for the notion of an association between female employment in the industry and earlier marriage, although as the SMAM for the county as a whole rose by 0.75 years, this rise is unimpressive. Removing the influence of the town of Great Berkhamsted, however, underlines this association for the rural parts of the region, for now the SMAM rises by just over two years from 24.84 to 26.86 . For the rural parishes in the St Albans region the rise is more muted, at 1.27 years, with the parishes of Redbourn, Wheathampstead and Sandridge registering substantial rises of $1.48,2.16$ and 2.78 years offset by the parish of Harpenden, where the straw trades held up better and where the SMAM actually fell by half a year. Comparison over time for the 15 parishes identified as providing the highest levels of employment in the straw industry for females in 1851 appears to confirm that at extreme levels female employment did generally have an impact upon age at marriage, for their collective SMAM rose by 1.52 years as the straw industry 
waned. In four of these parishes straw industry employment was relatively well

maintained, with over 60 per cent of employed females and over 25 per cent of all

females still in the industry by 1891 , and in these four collectively the SMAM rose by

just 0.67 years (from 25.44 to 26.11 ). In those eight parishes where the decline in

Table 10 Proportions of females ever-married in age groups 20-24, 15-44 and 45-54, 1851, 1871, 1891

\begin{tabular}{|c|c|c|c|c|c|c|c|c|c|c|}
\hline \multirow[t]{2}{*}{ SRD } & \multirow{2}{*}{$\begin{array}{l}\text { Straw } \\
\text { district }\end{array}$} & \multicolumn{3}{|c|}{1851} & \multicolumn{3}{|c|}{1871} & \multicolumn{3}{|c|}{1891} \\
\hline & & $20-24$ & $15-44$ & $45-54$ & $20-24$ & $15-44$ & $45-54$ & $20-24$ & $15-44$ & $45-54$ \\
\hline Ware & No & 31.0 & 53.2 & 88.7 & 27.8 & 50.8 & 89.9 & 23.6 & 47.3 & 85.4 \\
\hline Bishops Stortford & No & 31.1 & 52.1 & 86.6 & 31.5 & 52.0 & 90.4 & 23.2 & 47.9 & 87.5 \\
\hline Royston & No & 34.4 & 54.8 & 92.0 & 38.7 & 56.5 & 90.6 & 28.0 & 50.9 & 89.5 \\
\hline Hitchin & Yes & 35.0 & 50.8 & 88.3 & 28.9 & 47.7 & 86.9 & 25.0 & 46.3 & 85.0 \\
\hline Hertford & No & 31.7 & 51.8 & 88.7 & 28.9 & 50.5 & 87.4 & 25.4 & 47.2 & 84.8 \\
\hline Hatfield & No & 32.2 & 50.1 & 88.9 & 28.5 & 48.7 & 88.6 & 21.9 & 47.1 & 86.2 \\
\hline St Albans & Yes & 27.7 & 47.5 & 87.2 & 27.9 & 46.6 & 85.0 & 23.9 & 46.6 & 82.5 \\
\hline Watford & No & 26.7 & 51.0 & 90.8 & 27.6 & 48.0 & 75.5 & 24.1 & 46.2 & 80.2 \\
\hline Hemel Hempstead & Yes & 33.0 & 50.6 & 90.7 & 33.2 & 48.1 & 86.4 & 25.6 & 47.0 & 85.3 \\
\hline Berkhamsted & Yes & 28.6 & 48.0 & 86.4 & 24.3 & 47.9 & 86.3 & 24.9 & 46.7 & 84.8 \\
\hline Edmonton & No & 23.5 & 45.5 & 83.1 & $\mathrm{n} / \mathrm{a}$ & $\mathrm{n} / \mathrm{a}$ & $\mathrm{n} / \mathrm{a}$ & $\mathrm{n} / \mathrm{a}$ & $\mathrm{n} / \mathrm{a}$ & $\mathrm{n} / \mathrm{a}$ \\
\hline Barnet & No & 23.2 & 45.5 & 86.3 & $n / a$ & $\mathrm{n} / \mathrm{a}$ & $\mathrm{n} / \mathrm{a}$ & $\mathrm{n} / \mathrm{a}$ & $\mathrm{n} / \mathrm{a}$ & $\mathrm{n} / \mathrm{a}$ \\
\hline Hertfordshire & & 30.6 & 50.6 & 88.6 & 29.8 & 49.7 & 86.2 & 24.6 & 47.2 & 84.6 \\
\hline Straw SRDs & & 31.6 & 49.4 & 88.1 & 28.5 & 47.5 & 86.2 & 24.8 & 46.6 & 84.2 \\
\hline Non-straw SRDs & & 29.9 & 51.5 & 88.9 & 30.8 & 51.3 & 86.3 & 24.5 & 47.6 & 84.9 \\
\hline Top 15 straw parishes & & 34.2 & 51.2 & 88.1 & $n / a$ & $\mathrm{n} / \mathrm{a}$ & $\mathrm{n} / \mathrm{a}$ & 26.5 & 47.7 & 85.4 \\
\hline Straw parishes & & 32.2 & 49.9 & 88.7 & $\mathrm{n} / \mathrm{a}$ & $\mathrm{n} / \mathrm{a}$ & $\mathrm{n} / \mathrm{a}$ & $\mathrm{n} / \mathrm{a}$ & $\mathrm{n} / \mathrm{a}$ & $\mathrm{n} / \mathrm{a}$ \\
\hline Non-straw parishes & & 29.1 & 51.2 & 88.5 & $\mathrm{n} / \mathrm{a}$ & $\mathrm{n} / \mathrm{a}$ & $\mathrm{n} / \mathrm{a}$ & $\mathrm{n} / \mathrm{a}$ & $\mathrm{n} / \mathrm{a}$ & $\mathrm{n} / \mathrm{a}$ \\
\hline Rural straw parishes & & 36.0 & 52.3 & 90.0 & $\mathrm{n} / \mathrm{a}$ & $\mathrm{n} / \mathrm{a}$ & $\mathrm{n} / \mathrm{a}$ & $\mathrm{n} / \mathrm{a}$ & $\mathrm{n} / \mathrm{a}$ & $\mathrm{n} / \mathrm{a}$ \\
\hline Rural non-straw parishes & & 30.4 & 52.1 & 89.7 & $\mathrm{n} / \mathrm{a}$ & $\mathrm{n} / \mathrm{a}$ & $\mathrm{n} / \mathrm{a}$ & $\mathrm{n} / \mathrm{a}$ & $\mathrm{n} / \mathrm{a}$ & $\mathrm{n} / \mathrm{a}$ \\
\hline Urban parishes & & 25.4 & 46.7 & 85.7 & $n / a$ & $\mathrm{n} / \mathrm{a}$ & $\mathrm{n} / \mathrm{a}$ & $\mathrm{n} / \mathrm{a}$ & $\mathrm{n} / \mathrm{a}$ & $\mathrm{n} / \mathrm{a}$ \\
\hline Rural parishes & & 32.9 & 52.2 & 89.8 & $\mathrm{n} / \mathrm{a}$ & $\mathrm{n} / \mathrm{a}$ & $\mathrm{n} / \mathrm{a}$ & $\mathrm{n} / \mathrm{a}$ & $\mathrm{n} / \mathrm{a}$ & $\mathrm{n} / \mathrm{a}$ \\
\hline
\end{tabular}

Notes: 1851 data is calculated from the CEBs, that for 1871 and 1891 from the census reports.

The 1851 census report provides no information on marital condition by age group below the level of the county. 
employment was particularly marked, leaving under 10 per cent of the total female population employed in the straw industry by 1891 , the SMAM rose by 1.49 years (from 25.27 to 26.76). This more detailed analysis would, therefore, appear to confirm both an overall rise in average female age at marriage in late-nineteenth century Hertfordshire, and an exaggerated effect in those parishes experiencing the most significant declines from previously high levels of female employment in the straw industry.

In Table 10 data is presented for the proportion of the female population married in the age groups $20-24,15-44$ and $45-54$, the first to detect signs of early marriage, the second to compare the proportions of the fertile female population married, and the third as a surrogate measure of proportions ultimately marrying. The detailed, parishbased data available for 1851 produces clearer evidence of an association between earlier marriage and opportunities for female employment in the straw industry. Although again there is no consistent relationship by individual SRDs, the straw SRDs as a group exhibited a higher proportion of women marrying relatively young, while on every measure calculated from parish-level data higher proportions were married in the 20-24 age group in the straw areas, with a disparity approaching 6 per cent in the rural straw parishes compared to the rural non-straw parishes. In terms of those married in the fertile age groups, however, there is little difference, while proportions ultimately marrying are also very similar. Again significant differences are evident between urban and rural areas, while the two SRDs situated on the 
London fringes exhibit notably low proportions married aged 20-24, and also in the age range $15-44$.

Changes between 1851 and 1891 faithfully reflects the direction of the changes discovered for the SMAM. Proportions married decline in every age group, for the county as a whole and for straw and non-straw SRDs alike, resulting in a very similar profile by 1891 . Data for the 15 parishes identified as providing the highest levels of employment in the straw industry for females in 1851 shows even greater change, however, the proportion married aged 20-24 falling by 7.7 per cent 1851-91. In those eight parishes where employment in the straw industry had fallen most significantly the proportion married in the age group 20-24 fell from 31.5 per cent to just 24.8 per cent, while in the four parishes where employment was best maintained it fell less markedly, from 36.0 per cent to 30.5 per cent, again suggesting that rapidly declining opportunities for employment in the straw industry in those areas where it was once heavily concentrated did indeed impact upon female age at marriage, removing an incentive or opportunity to marry early.

Although for 1871 data is only available at the level of the SRD it shows higher proportions married at age 20-24 in the non-straw regions and, as the straw industry was now at its height, would appear to contradict the evidence discussed so far. There are a number of possible explanations, the first of which is the relative insensitivity of analysis at the level of the SRD as compared with the parish, clearly shown in the 1851 data. Second is the undue influence amongst the non-straw areas of Royston, 
where the sex ratio among 20-24 year-olds in 1871 stood at 115 , and approaching 39 per cent of females ages 20-24 were married: the removal of Royston virtually eradicates the difference between the two groups. Third, and perhaps most significantly, the impact of female employment opportunities upon the sex ratio intensified as those opportunities increased. Table 7 has already explored these trends for the age groups 15-24 and 25-34, but they were particularly marked for those aged 20-24. For this age group, in the straw SRDs collectively the sex ratio fell from 88 in 1851 to just 77 in 1871 , the figures for the non-straw areas standing at 110 and 97 respectively. Of the straw SRDs only Hemel approached the county average of 89 with a sex ratio of 87 , and it is notable that here the proportions marrying young held up far better than they did in Berkhamsted, St Albans and Hitchin. Nor did the sex ratio recover thereafter in the straw regions for, as Table 7 shows, it remained at 77 for the age group 25-34, helping to explain the discrepancy between proportions married in straw and non-straw SRDs at ages 15-44. Although further exploration at parish level is clearly needed, as both Anderson and Woods and Hinde found a strong negative relationship between a female-skewed sex ratio and propensity to marry in 1861 (the latter laying particular emphasis upon the importance of the 20-24 age group) our local evidence appears to reflect this process, the encouragement to marry young provided by female employment prospects eventually falling foul of an imbalance between the sexes that was the product of those very same opportunities. ${ }^{71}$

Table 11 presents the results of calculation of Coale's indices for nuptiality (Im and $\operatorname{Im} *$, employing the age and marital structure found in Hertfordshire to compare 
nuptiality against the levels achieved by the Hutterite community in the United States in the $1920 \mathrm{~s} .{ }^{72}$ Although this index has been described as 'the best single standardized index of the level of nuptiality which may be calculated from the available data', it is in fact a composite measure, combining the effects of age at marriage and proportions

Table 11 Coale's indices of nuptiality, 1851, 1871, 1891

\begin{tabular}{|c|c|c|c|c|c|c|c|}
\hline \multirow[t]{2}{*}{ SRD } & \multirow{2}{*}{$\begin{array}{l}\text { Straw } \\
\text { district }\end{array}$} & \multicolumn{2}{|c|}{1851} & \multicolumn{2}{|c|}{1871} & \multicolumn{2}{|c|}{1891} \\
\hline & & Im & $\mathrm{Im}^{*}$ & Im & $\mathrm{Im}^{*}$ & Im & $\mathrm{Im}^{*}$ \\
\hline Ware & No & & & 0.490 & 0.436 & 0.456 & 0.401 \\
\hline Bishops Stortford & No & & & 0.510 & 0.465 & 0.457 & 0.406 \\
\hline Royston & No & & & 0.559 & 0.506 & 0.497 & 0.440 \\
\hline Hitchin & Yes & & & 0.462 & 0.431 & 0.447 & 0.403 \\
\hline Hertford & No & & & 0.486 & 0.441 & 0.458 & 0.412 \\
\hline Hatfield & No & & & 0.470 & 0.431 & 0.457 & 0.395 \\
\hline St Albans & Yes & & & 0.446 & 0.410 & 0.447 & 0.396 \\
\hline Watford & No & & & 0.463 & 0.408 & 0.441 & 0.388 \\
\hline Hemel Hempstead & Yes & & & 0.463 & 0.423 & 0.451 & 0.405 \\
\hline Berkhamsted & Yes & & & 0.458 & 0.415 & 0.453 & 0.405 \\
\hline Hertfordshire & & 0.495 & 0.453 & 0.481 & 0.436 & 0.454 & 0.403 \\
\hline Straw SRDs & & & & 0.457 & 0.420 & 0.449 & 0.402 \\
\hline Non-straw SRDs & & & & 0.498 & 0.448 & 0.458 & 0.405 \\
\hline
\end{tabular}

marrying, and hence provides a rather blunt tool, providing no insight into agespecific trends. ${ }^{73}$ Furthermore, as the 1851 census report provides no information on age and marital condition below county level, and the digitized census data from the CEBs fails to match the data for births, marriages and deaths for the registration county for four out of ten districts, these indices can only at present be calculated for the registration county of Hertfordshire for 1851 . Nevertheless, at county level these figures amply confirm the long-term decline in nuptiality indicated by both the 
SMAM and by proportions married in different age groups. The higher levels of nuptiality found in the non-straw districts in 1871 is also confirmed, while the smaller discrepancy apparent once age structure is allowed for ( $\left.\mathrm{Im}^{*}\right)$ supports the argument offered above regarding the impact of sex-selective migration on proportions married. Finally, Table 11 indicates convergence by 1891, both between individual SRDs and between straw and non-straw regions of the county.

\section{$\mathbf{V}$}

Through to the 1880 s the straw plait and hat trades provided substantial employment opportunities for both single and married women over much of west, and particularly south-west, Hertfordshire, reaching levels that compare favourably with those discovered to date for any substantial economic region in England. Despite periodic depressions and a degree of seasonality in the trade, wages stood at levels that must have facilitated saving towards marriage, and provided a valuable contribution to family budgets once marriage had taken place. Rural earnings, largely from straw plaiting, were probably inadequate to underpin female independence, however, and few girls appear to have left home early and few young women established their own households, even if their number was slightly higher in the straw industry regions than it was elsewhere in the county. In the town of St Albans where earnings were higher slightly larger numbers took advantage of these opportunities, but the number here also remained relatively small. 
In nineteenth-century Hertfordshire there was a general association between areas where opportunities arose for women and children to work in the straw plait and hat trades and demographic vitality, most notably in the first half of the century, that vitality waning as the industry declined from the 1870 s, at least in areas lacking countervailing influences, such as significant urban development. In part this early growth was fuelled by sex-selective migration or — with the same result - - sexselective retention of population. Towards the end of the century, however, the declining straw plait areas were losing a higher proportion of their natural increase through net migration than were the non-straw districts.

Calculation of the SMAM and proportions ever-married in various age groups indicate that in 1851, far from providing a disincentive to marry young, the straw plait and hat trades encouraged or permitted earlier marriage. While the differences between the straw and non-straw areas were relatively small, it must be remembered that this was achieved in the face of a distinctly skewed sex ratio in these areas, the product of sex-selective net migration, which served to limit the number of potential male marriage partners. In those parishes where the industry was most heavily concentrated, and in rural straw parishes, this tendency was particularly marked. This conclusion highlights the importance of analysis at the local level, for averages across the SRDs can easily obscure distinctive local labour and marriage markets, and also aggregate urban and rural experiences that were often quite dissimilar. The data for 1871, only available at SRD level, appears to contradict the results found twenty years earlier. But apart from the fact that this data is far less sensitive to local variation, and 
is heavily influenced by the exceptional experience of the Royston district, the results may be the product of the increasingly skewed sex ratio among those in their early twenties in these areas, producing a situation where-whatever young women desired - there were simply too few suitable men to go round.

Despite this tendency towards earlier marriage in the straw areas at mid-century, this did not translate into higher proportions married in the child-bearing age groups, or higher proportions ultimately married. The age-specific data suggests little difference between straw and non-straw areas throughout the period in terms of proportions ultimately marrying, while both this data and Coale's indices of $\mathrm{Im}$ and $\mathrm{Im}$ * reveal higher proportions married overall in the non-straw areas in 1871 . The tendency towards early marriage was, therefore, compensated by lower nuptiality in the higher age groups. Persistently skewed sex ratios into the later twenties and early thirties, when most marriages took place, in contrast to the more balanced scenario in the nonstraw agricultural areas, lies behind these results, and the increasing skew in this age group as the industry reached its height by 1871 produced a marked deficit in the straw SRDs, measured both by proportions married aged 15-44 and by Coale's indices of overall nuptiality.

By 1891 when the straw plait and hat trades were declining rapidly, while on all measures levels of nuptiality had declined across Hertfordshire as a whole, the mean age at marriage in the key rural straw regions of the county had risen particularly sharply, while in terms of proportions married at different ages and the overall index 
of nuptiality any distinction that had previously been apparent between straw and nonstraw areas was either far more muted or had disappeared completely. Indeed, one of the key features of nuptiality in late nineteenth century Hertfordshire was convergence, both between straw and non-straw areas and between different regions more generally.

The results presented here, therefore, provide very limited support to the proponents of proto-industrial theory, despite the association between the development of the industry and demographic vitality and an indication, in 1851 at least, of encouragement to early marriage, if not to marriage in general. But nor does the evidence presented here endorse the view that industrial employment for women led to delayed marriage as it seems to have done in areas of textile production, although it may have impacted upon levels of nuptiality overall, suggesting that distinctions must be drawn between factory-based and cottage industry. If it did serve to delay marriage, this was as much the product of the skewed sex ratio found in such areas, the product of sex-selective net migration, as of any influence exerted by female employment prospects per se. If the direct effect of earning opportunities for women, given the prevailing social and cultural norms of nineteenth century England, was to encourage earlier female marriage — most notably in those areas where the industry was particularly heavily concentrated - the indirect effect was to reduce marital opportunity by producing a skewed sex ratio, via patterns of net migration, that could eventually negate the positive, direct effect. 
A complex array of factors, some intertwined, others independent, lay behind the patterns of population growth, migration and nuptiality that have been identified for later nineteenth-century Hertfordshire. ${ }^{74}$ Employment in the straw industry was only one of these, and one must remember that even in the four SRDs where the trade was clearly prominent, more than four women out of every ten employed worked in occupations other than straw. This complexity underlines the importance of looking below the level of the SRD where possible, to identify the prime straw industry areas more accurately, to remove the countervailing effects of towns and other influences, and hence to negate as far as is possible the charge of falling foul of the ecological fallacy. But there are, of course, other factors apart from female employment opportunities that deserve attention, and proximity to London is one of these, particularly in view of the high age at marriage found in Barnet and Edmonton at midcentury and their increasingly rapid growth as the century progressed. Conversely, some of the most agricultural areas of the county, most notably Royston which lay farthest from the capital, also possessed distinctive patterns of nuptiality which deserve closer attention than has been possible here, particularly the sharp contrast in their demographic experience between the periods of 'high farming' and 'agricultural depression'. But there is one final conclusion to be drawn from this study that is quite clear, for on so many measures, where it is possible to distinguish town from countryside, there are distinct — even overriding — urban/rural differences. Some of these may have reinforced features also generally apparent in straw districts (such as a female-skewed sex ratio), others may have counteracted that influence (such as the deterrent effect upon marriage of higher levels of domestic service), and hence serve 
to cloud the demographic impact of the industry per se. Even small towns of the order found in nineteenth-century Hertfordshire, therefore, possessed a distinctive demography, and their further exploration is another item to add to the agenda of nineteenth-century population history.

\section{Nigel Goose}

October 2004

Revised September 2005.

\footnotetext{
${ }^{1}$ H. Medick, 'The proto-industrial family economy: the structural function of household and family during the transition from peasant society to industrial capitalism', Social History, 3 (1976), 291-315; D. Levine, Family formation in an age of nascent capitalism (New York, 1977); Levine, Reproducing families (Cambridge, 1987). For a valuable summation and assessment of the thesis see L.A. Clarkson, Proto-industrialisation: the first phase of industrialisation? (London, 1985).

${ }^{2} \mathrm{H}$. Medick, 'The structures and function of population development under the proto-industrial system', in P. Kriedte, H. Medick and J. Schlumbohm, Industrialization before Industrialization: rural industry in the genesis of capitalism (Cambridge, 1982), 74.

${ }^{3}$ J.D. Chambers, The Vale of Trent 1670-1800: a regional study of economic change, Economic History Review Supplement, 3 (1957).

${ }^{4}$ Chambers, Vale of Trent, $13-18$

${ }^{5}$ Chambers, Vale of Trent, 33-5, 52-3. These arguments are also summarised in his contribution to D.V. Glass and D.E.C. Eversley eds, Population in history: essays in historical demography (London, 1965), pp. 328-34, and in J.D. Chambers, Population, economy and society in pre-industrial England (Oxford, 1972), 63-5.

${ }^{6}$ Chambers, Vale of Trent, 33.

${ }^{7}$ E.A. Wrigley, R. Davies, J. Oeppen and R.S. Schofield, English population history from family reconstitution 1580-1837 (Cambridge, 1997), 134, 184-5, 549-50; D. Levine, 'Industrialisation and the proletarian family in England', Past and Present, 107 (1985), 183.

${ }^{8}$ Wrigley et al., English population history, 191.

${ }^{9}$ P. Hudson and S. King, 'Two textile townships, c. 1660-1820: a comparative demographic analysis', Economic History Review, 53 (2000), 706-41. For further scepticism see P. Hudson, 'Industrialization in Britain: the challenge of micro-history', Family \& Community History, 2 (1999), 8-9.

${ }^{10}$ Quoted in M. Anderson, 'Marriage patterns in Victorian Britain: an analysis based on a registration district sample for England and Wales 1861', Journal of Family History, 1 (1976), 66.

${ }^{11}$ K.D.M. Snell, Annals of the labouring poor. Social change and agrarian England 1660-1900 (Cambridge, 1985), 212, 346.

${ }^{12}$ Snell, Annals, 212-13, 346-52.
} 
${ }^{13}$ Anderson, 'Marriage patterns in Victorian Britain'.

${ }^{14}$ R.I. Woods and P.R.A. Hinde, 'Nuptiality and age at marriage in nineteenth-century England', Journal of Family History, 10 (1985), 119-44. This uncertainty with regard to Anderson's position is echoed by Bridget Hill: 'The marriage age of women and the demographers', History Workshop, 28 (1989), 136.

${ }^{15}$ Woods and Hinde, 'Nuptiality', 131, 134, 140.

${ }^{16}$ Woods and Hinde, 'Nuptiality', 134, 141. See also P.R.A. Hinde, 'Household structure, marriage and the institution of service in nineteenth-century rural England', Local Population Studies, 35 (1985), 43-51.

${ }^{17}$ R. Lawton and C.G. Pooley, Britain 1740-1950. An historical geography (London, 1992), 124-5.

${ }^{18}$ B. Woods, The demography of Victorian England and Wales (Cambridge, 2000), 93.

${ }^{19}$ Woods, Demography, 157.

${ }^{20}$ B. Reay, Microhistories: demography, society and culture in rural England, 1800-1930 (Cambridge, 1996), pp. 39-67. See also his Rural Englands (Basingstoke, 2004), 94-8. The Cambridge Group mean from 26 parish reconstitutions stands at 23.5 years for the early $19^{\text {th }}$ century.

${ }^{21}$ Woods, Demography, 95, 98-99; R.I. Woods and C.W. Smith, 'The decline of marital fertility in the late nineteenth century: the cae of England and Wales', Population Studies, 37 (1983), 207-25; E.M. Garrett, 'The trials of labour: motherhood versus employment in a nineteenth-century textile town', Continuity and Change, 5 (1990), 121-54; Hinde, 'Household structure'; Hinde, 'The marriage market in the nineteenth-century English countryside', Journal of European Economic History, 18 (1989), 383-92.

${ }^{22}$ These figures are as published in L.L. Grof, Children of Straw. The story of a vanished craft industry in Bucks, Herts, Beds and Essex (Buckingham, 1988), 29. They relate only to straw plaiters, where these can be distinguished. For accuracy, 1,671 female straw hat and bonnet makers should be added to the Hertfordshire figure for 1851, and 1,289 for 1901. Hat and bonnet makers are included in the figures for 1871, 1881 and 1891. The long-term trends are unaffected by these adjustments.

${ }^{23}$ L.L. Grof, Children of Straw. The story of a vanished craft industry in Bucks, Herts, Beds and Essex (Buckingham, 1988), 103; P. Sharpe, Adapting to capitalism, Working women and the English economy, 1700-1850 (Basingstoke, 1996), 62; W. Page (ed.), The Victoria History of the County of Hertfordshire, 4 vols. (London, 1904-14), vol. 4, 255; N. Goose, Population, economy and family structure in Hertfordshire in 1851. Vol. 2 St Albans and its region (Hatfield, 2000), 70-2.

${ }^{24}$ These remarks apply to the ancient (or geographical) county, which either wholly or partly embraced 12 Superintendant Registrar's Districts (SRDs), although only 10 were largely situated within Hertfordshire, and formed the registration county as defined in the published census reports: Ware, Bishops Stortford, Royston, Hitchin, Hertford, Hatfield, St Albans, Watford, Hemel Hempstead and Berkhamsted. Parts of the Barnet and Edmonton SRDs lay in the ancient county, while parts of the Royston SRD was situated in Cambridgeshire. The SRDs correspond to the Registration Districts of the Registrar General's Annual Reports; the 28 Registrar's Districts into which the county was divided correspond to the sub-districts in the Annual Reports.

${ }^{25}$ E. Grey, Cottage life in a Hertfordshire village (St Albans, 1935), 57, 68, 70.

${ }^{26}$ Royal Commission on the Employment of Children, Young Persons and Women in Agriculture (1867), British Parliamentary Papers 1867-1868, XVII, Appendix Part II, pp. 498-9..

${ }^{27}$ N. Goose, Population, economy and family structure in Hertfordshire in 1851. Vol. 1 The

Berkhamsted region (Hatfield, 1996), 38; Goose, St Albans and its region, 90; Hemel Hempstead calculations from Census Enumerators Books, PRO HO 107/1715; M. Anderson, Family structure in nineteenth century Lancashire (Cambridge, 1971), 71, 208 fn.32; M.W. Dupree, Family structure in the Staffordshire potteries 1840-1880 (Oxford, 1995), 147-8, 169-70.

${ }^{28}$ For fuller details see Goose, St Albans and its region, 90-7.

${ }^{29}$ S.Horrell and J. Humphries, 'Women's labour force participation and the transition to the male breadwinner family, 1790-1865', Economic History Review, 48 (1995), 102-5.

${ }^{30}$ Ibid., 106-7.

${ }^{31}$ Ibid., 105; J. Humphries and K.D.M. Snell, 'Introduction', to P. Lane, N. Raven and K.D.M. Snell eds, Women, work and wages in England, 1660-1850 (Woodbridge, 2004), 1-14, cited at p. 14.

${ }^{32}$ Horrell and Humphries, 'Women's labour force participation', 102-3, 107. 
${ }^{33}$ Report of the Royal Commission of the Poor Laws, British Parliamentary Papers 1834, XXX, pp. $217,224,226$.

${ }^{34}$ Ibid., 217, 219, 222, 227.

${ }^{35}$ R.M. Gutchen (ed.), On the sanitary condition of the Hitchin Union Workhouse 1842 (Hoddesdon, 1972, unpaginated).

${ }^{36}$ Children's Employment Commission: Second Report (Trades and Manufactures), British

Parliamentary Papers 1843, XIII, p. 132.

${ }^{37}$ Royal Commission on the Employment of Children, Young Persons and Women in Agriculture (1867), British Parliamentary Papers 1867-1868, XVII, Appendix Part I, p. 135.

${ }^{38}$ The Children's Employment Commission Report may well be the original source for the figures of 3s. 6d. - 4s. 0d. per week cited in R.C. Allen, Enclosure and the yeoman (Oxford, 1992), p. 256. In 1804 Young reported earnings for female plaiters of 21 shillings per week in Redbourn and Dunstable, 14-18 shillings in Berkhamsted and up to 5 shillings per day in St Albans, with 42 shillings being achieved 'for a short time': A. Young, General view of the agriculture of Hertfordshire (repr. Newton Abbot, 1971, $1^{\text {st }}$ publ. 1804), pp. 217-20.

${ }^{39}$ Report of the Select Committee of the House of Lords on the Poor Laws, British Parliamentary Papers,1831, VIII, pp. 277, 279.

${ }^{40}$ Children's Employment Commission: Second Report of the Commissioners on Children's Employment, British Parliamentary Papers 1864, XXII, p. 203.

${ }^{41}$ Royal Commission on the Employment of Children, Young Persons and Women in Agriculture (1867), British Parliamentary Papers 1867-1868, XVII, Appendix Part I, p. 136.

${ }^{42}$ A.J. Tansley,' On the straw plait trade', Journal of the Society of Arts, IX (1860), 69-77.

${ }^{43}$ Ibid., pp. 71-2; Report from the House of Lords Select Committee on the Poor Laws (1817), British

Parliamentary Papers 1818, V, p 94; Children's Employment Commission: Second Report of the Commissioners on Children's Employment, British Parliamentary Papers 1864, XXII, p. 203; Grey, Cottage life, p. 67.

${ }^{44}$ Children's Employment Commission: Second Report of the Commissioners on Children's Employment, British Parliamentary Papers 1864, XXII, pp. 200, 206-8.

${ }^{45}$ Young, General view of the agriculture of Hertfordshire, pp. 217-20; G. Mingay, ed., The Agrarian History of England and Wales, VI 1750-1850 (Cambridge, 1989), p. 1095; F. Purdy, 'On the earnings of agricultural labourers in England and Wales, 1860', Journal of the Royal Statistical Society, 25 (1861), p. 342.

${ }^{46} \mathrm{P}$. Sharpe, 'The women's harvest: straw-plaiting and the representation of labouring women's employment, c. 1793-1885', Rural History, 5 (1994), p. 136.

${ }^{47} \mathrm{~J}$. Burnett ed., Useful toil. Autobiographies of working people from the 1820s to the 1890s (London, 1974), p. 77.

${ }^{48}$ Tansley, 'On the straw plait trade', p. 71.

${ }^{49}$ Grey, Cottage life, pp. 70, 90, 118-19.

${ }^{50}$ Report of the Royal Commission of the Poor Laws, British Parliamentary Papers 1834, XXX, pp. 222, 224, 225, 227.

${ }^{51}$ Children's Employment Commission: Second Report of the Commissioners on Children's Employment, British Parliamentary Papers 1864, XXII, p. 204.

52 Ibid., p. 207.

${ }^{53}$ Children's Employment Commission: Second Report (Trades and Manufactures), British Parliamentary Papers 1843, XIV, Appendix, p. A13. Cf. Sharpe, 'The women's harvest', p. 137.

${ }^{54}$ Tansley. 'On the straw plait trade', p. 72; C. Freeman, Luton and the hat industry (Luton, 1953), p. 12; P. Horn, 'Child workers in the pillow lace and straw plait trades of Victorian Buckinghamshire and Bedfordshire', Historical Journal, 4 (1974), p. 789.

${ }^{55}$ This issue will be discussed at much greater length in my 'Illegitimate fertility and the family : the impact of the straw plait and hat trades in nineteenth-century Hertfordshire' (forthcoming).

56 Two more female teenagers heading households were silkworkers.

${ }^{57}$ National data has been taken from N.L. Tranter, Population and society 1750-1940: contrasts in population growth (London, 1985), and R. Woods, The population of Britain in the nineteenth century (Cambridge, 1992). 
${ }^{58}$ R. Schofield, Parish register aggregate analyses: the Population history of England database and introductory guide, a Local Population Studies Supplement (Colchester, 1998).

${ }^{59}$ For under-registration and suggested correction factors see E.A. Wrigley and R.S. Schofield, The population history of England 1541-1871: a reconstruction (London, 1981), pp. 103-54, cited here at 131.

${ }^{60}$ Calculated from Annual Reports of the Registrar General for Births, Marriages and Deaths, 1837 1901, 65 vols (London, 1839-1902).

${ }^{61}$ Tranter, Population and society, pp. 44, 59; Woods, Population of Britain, p. 17.

${ }^{62}$ See, for instance, D. Mills and K. Schürer, eds, Local communities in the Victorian census enumerators' books (Oxford, 1996), pp. 223-7.

${ }^{63}$ To demonstrate, take two hypothetical parishes each with a native population in a particular cohort of 100. In the 'attractive' parish only 20 leave and 40 immigrants arrive, which produces a native population of $66.66 \%$ and an immigrant population of $33.33 \%$. In the 'unattractive' parish as many as 50 leave and only 25 arrive, producing a native population of $66.66 \%$ and an immigrant population of $33.33 \%$. Exactly the same proportions result from two very different scenarios.

${ }^{64}$ For a similar view on the importance of sex-selective net migration and its reflection in sex ratios for the period 1871-1881 see D. Friedlander and E.B. Moshe, 'Occupations, migration, sex ratios, and nuptiality in nineteenth century English communities: a model of relationships', Demography, 23 (1986),pp. 1-12.

${ }^{65}$ M. Anderson, 'The social implications of demographic change', in F.M.L. Thompson ed., The Cambridge social history of Britain 1750-1950. Vol. 2 People and their environment (Cambridge, 1990), pp. 18-19; R.Woods and J. Shelton, An atlas of Victorian mortality (Liverpool. 1997), pp. $107-$ 8.

${ }^{66}$ British Parliamentary Papers 1861, XVI, Third report of the medical officer of the privy council, $1860,34-5,182-3$. Female mortality from pulmonary diseases for 1848-54 in the Berkhamsted SRD is given as 5.66 per 1,000 , male as either 4.01 or 4.91 (both figures are given in different parts of the report). In 1855-59 the figures were 6.02 and 4.80 respectively. For both periods the figures given for the southern standard (calculated from six SRDs in Surrey and Sussex) were 4.54 for females and 4.11 for males. Friedlander and Moshe maintained that 'no major district variations in mortality sex differentials are known for the nineteenth century period, and where sex selective mortality may have been present it ws likely to have had a very small influence on sex ratios as compared to the substantial migration effects': 'Occupations, migration, sex ratios, and nuptiality', p. 1. The second part of this sentence may be true, but this really depends upon fuller exploration of the first part.

${ }^{67}$ It is, of course appreciated that the behaviour of the male population also has a bearing on these ratios, and hence the analysis is incomplete, but the contrast with the non-straw areas supporst to the hypothesis presented here. For a sophisticated method to pursue age and sex specific migration more deeply, unfortunately too elaborate to be applied on the scale of analsysis used here, see A. Hinde. 'The use of nineteenth-century census data to investigate local migration', Local Population Studies, 73 (2004), pp. 8-28.

${ }^{68}$ For calculation of the singulate mean age at marrriage see J. Hajnal, 'Ages at marriage and proportions marrying', Population Studies, 7 (1953), pp. 111-36; K. Schürer, 'A note concerning the calculation of the singulate mean age at marriage', Local Population Studies, 43 (1989), pp. 67-9; M. Drake and R. Finnegan (eds), Sources and methods for family and community historians: a handbook (Cambridge, 1994), p. 185.

${ }^{69}$ Wrigley and Schofield, Population history of England, Table 10.3, p. 437; Schürer, 'A note', p. 69. Drake and Finnegan repeat Schürer's calculations for the same population but produce a result of 25.86, which is due to their accidental inclusion of the age group 50-54 in calculation of the number of years of singleness: Drake and Finnegan, Sources and methods, p. 185.

${ }^{70}$ Two of the four straw SRDs, Berkhamsted and St Albans, were particularly urbanized in Hertfordshire terms, with $53 \%$ and $40 \%$ respectively in towns compared to the county average of $24 \%$ : Goose, St Albans and its region, 33.

${ }^{71}$ Anderson, 'Marriage patterns in Victorian Britain', pp. 61-9; Woods and Hinde, 'Nuptiality', pp. 127-8. More recently Woods writes, 'the sex ratio among 20-24-year-olds holds a key position in influencing the level of nuptiality’: Woods, Population of Britain, p. 93. 
${ }^{72}$ The clearest explanation of how to calculate these rates in in R. Woods, Population analysis in geography (London, 1979), pp. 118-20. Their calculation from the published census reports, however, requires the recalculation of appropriate fertility schedules for the different age groups employed in these reports, which can be established by reference to the data for each age of life published in J.W. Eaton and A.J. Mayer, 'The sociology of very high fertility among the Hutterites. The demography of a unique population', Human Biology, XXV (1953). Im takes no account of the proportion of women married in each age group, $\mathrm{Im}^{*}$ eliminates the influence of age structure.

${ }^{73}$ Woods and Hinde, 'Nuptiality', p. 121.

${ }^{74}$ For a welcome discussion of the complexity of the issue, an insistence that a wider array of factors than just women's earning potential should be considered and a call for more work on the distinctive marriage patterns of local communities see Hill, 'Marriage age of women and the demographers'. 